\title{
Intravenous energy infusion in lambs: effects on nitrogen retention, plasma free amino acids and plasma urea nitrogen*
}

\author{
By B. ESKELAND, $\uparrow$ W. H. PFANDER AND R. L. PRESTON + \\ Department of Animal Husbandry, University of Missouri, \\ Columbia, Missouri 65201, USA
}

(Received 5 April 1973-Accepted 2 fuly 1973)

\begin{abstract}
I. Acetate, propionate, butyrate and glucose were each administered intravenously ( $2 \cdot 09 \mathrm{MJ}$ $(0.5 \mathrm{Mcal}) / \mathrm{d})$ to lambs on either high-concentrate $(\mathrm{HC})$ or high-roughage (HR) diets in two experiments with $4 \times 4$ Latin square design. During a control period all animals received a saline infusion.

2. In lambs on the HC diet glucose was the most effective metabolite tested for improving nitrogen retention. Acetate was $5 \mathrm{I} \%$, butyrate, $75 \%$, propionate, $90 \%$ as effective as glucose in promoting $\mathrm{N}$ retention. Propionate infusion was most effective in increasing $\mathrm{N}$ retention in lambs on the HR diet. Acetate was $60 \%$, butyrate, $75 \%$, and glucose, $80 \%$ as effective as propionate: Glucose infusion did not lower plasma urea $\mathrm{N}$ (PUN) concentration in lambs receiving the $\mathrm{HC}$ diet, but the three volatile fatty acids (VFA) did lower it $(P<0.0 \mathrm{I})$. All energy sources significantly reduced the PUN concentrations with the HR diet, but differences between sources were not significant.

3. Plasma concentrations of valine, isoleucine, leucine and phenylalanine were depressed to $57,7 \mathrm{r}, 89$ and $90 \%$ of their control values during glucose, propionate, butyrate and acetate infusion. Plasma concentrations of lysine and methionine were significantly decreased from control values $(P<0.05)$ but there was no significant difference between energy sources. Lysine, valine, isoleucine and leucine were significantly $(P<0.01)$ higher in lambs given the HR diet than in lambs given the HC diet. The concentration of alanine was greater $(P<0.05)$ during glucose infusion than during acetate and butyrate infusions, indicating net synthesis of alanine and possibly other non-essential amino acids during glucose infusion, since the plasma free amino acid $N$ concentration increased despite decreased concentrations of plasma essential amino acids during glucose infusion.

4. The results indicated that glucose and propionate were superior to acetate and butyrate as energy sources for protein formation.

5. The poor relationship between PUN and $\mathrm{N}$ balance and plasma free cssential amino acids suggested that PUN concentration may have been inappropriate to assess the protein status under some dietary conditions.
\end{abstract}

The three major volatile fatty acids (VFA) produced by rumen fermentation have not been widely investigated as sources of energy in protein synthesis in lambs. Rook, Balch, Campling \& Fisher (1963) and Ørskov \& Allen (I966) found no significant differences between the effects of the three major VFA on nitrogen retention when they were infused into the rumen or given as their salts in the food. Eskeland, Preston \& Pfander (197I) and Eskeland, Pfander \& Preston (1973) found that propionate promoted a higher $\mathrm{N}$ retention than butyrate, and acetate was the least effective when the respective energy sources were administered intravenously on an isoenergetic basis. All VFA were utilized less efficiently than glucose.

The free amino acid concentration in blood of simple-stomached animals has been

* Contribution from the Missouri Agricultural Experiment Station Journal Series No. 6402. Approved by the Director.

+ Present address: Agricultural College of Norway, 1432 Vollebekk, Norway.

$\ddagger$ Present address: Ohio Agticultural Research and Development Center, Wooster, Ohio, USA. 
Table I. Gross, chemical and energy compositions of the high-concentrate and highroughage diets given to 4-month-old lambs in Expt I and Expt 2, respectively

Component

Cottonseed hulls
Lucerne hay, chopped
Molasses, cane
Maize, steam-rolled
Soya-bean meal, 44\% crude protein
(solvent-extracted)
Limestone
Cobalt, iodized salt*
Vitamin premix $\uparrow$

High-concentrate diet High-roughage diet

rross composition $(\mathrm{g} / \mathrm{kg})$

Chemical and energy composition

Crude protein $(\mathrm{g} / \mathrm{kg})$
Digestible energy:
MJ $/ \mathrm{kg}$
Mcal $/ \mathrm{kg}$
Cellulose $(\mathrm{g} / \mathrm{kg}) \dagger$
Lignin $(\mathrm{g} / \mathrm{kg})\rfloor$
Acid-detergent fibre $(\mathrm{g} / \mathrm{kg})+$
Neutral-detergent fibre $(\mathrm{g} / \mathrm{kg})+$
Fat $(\mathrm{g} / \mathrm{kg})$
Fibre $(\mathrm{g} / \mathrm{kg})$
Ash $(\mathrm{g} / \mathrm{kg})$
Calcium $(\mathrm{g} / \mathrm{kg})$
Phosphorus $(\mathrm{g} / \mathrm{kg})$
Potassium $(\mathrm{g} / \mathrm{kg})$
Sodium $(\mathrm{g} / \mathrm{kg})$

$\begin{array}{rr}100.0 & 295.0 \\ 100 \cdot 0 & 400.0 \\ 406.0 & 100.0 \\ 370.0 & \\ 9.0 & 190.0 \\ 5.0 & 5.0 \\ 10.0 & 10.0\end{array}$

\begin{tabular}{|c|c|}
\hline 21844 & $145^{\prime} 9$ \\
\hline I $2 \cdot 35$ & 9.42 \\
\hline $2 \cdot 95$ & $2 \cdot 25$ \\
\hline I I I. O & 324.0 \\
\hline $27^{\circ} 0$ & o \\
\hline $137^{\circ} \circ$ & $394^{\circ} \circ$ \\
\hline $299^{\circ} 0$ & 505.0 \\
\hline 234 & I $8 \cdot 5$ \\
\hline $90 \cdot 6$ & $255^{\circ} 4$ \\
\hline $\begin{array}{r}59 \cdot 1 \\
6 \cdot 0\end{array}$ & $\begin{array}{r}73.2 \\
6.8\end{array}$ \\
\hline $3 \cdot 9$ & $2 \cdot 6$ \\
\hline I 5.2 & $22 \cdot 3$ \\
\hline $2 \cdot 4$ & $2 \cdot 4$ \\
\hline
\end{tabular}

* Iodized salt containing $225 \mathrm{mg} \mathrm{CoCl} 2 \cdot 6 \mathrm{H}_{2} \mathrm{O} / \mathrm{kg}$.

+ Supplied $\mathrm{I} 500 \mu \mathrm{g}$ vitamin $\mathrm{A}$ and $\mathrm{I} 6 \mu \mathrm{g}$ vitamin $\mathrm{D} / \mathrm{kg}$ diet.

\pm Van Soest fibre analysis (Van Soest, 1967).

studied with respect to the effects of dietary energy and protein concentrations. The studies of Potter, Purser \& Cline (I968) have reported the effect of these variables on the free amino acid concentration in the blood plasma of ruminants.

Since the results of the preceding studies indicated that the relative values of the three major VFA as energy sources in protein synthesis were different, it seemed appropriate to measure the plasma free amino acid concentrations and to relate them to the abilities of the three individual major VFA and glucose to promote $\mathrm{N}$ retention.

It appears from the literature that determination of blood urea content is an accurate and rapid method for elucidating the protein status of the animal (Preston $\&$ Pfander, I963). This criterion was applied to evaluate the effectiveness of the energy sources for promoting $\mathrm{N}$ balance. Two experiments were conducted to relate $\mathrm{N}$ balance to plasma free amino acid concentrations and plasma urea nitrogen (PUN) concentrations when lambs on high- and low-concentrate diets were intravenously infused with either glucose or one of the three VFA, acetic, propionic or butyric. A preliminary abstract of these studies has been published (Eskeland, Pfander, Badger \& Preston, 1971). 


\section{EXPERIMENTAL}

Two experiments were conducted simultaneously during the summer of $197^{\circ}$ and ten 4 -month-old lambs weighing between $27^{\circ} 0$ and $28.5 \mathrm{~kg}$ were allocated to the experiments. In Expt $\mathrm{I}$ a high-concentrate (HC) diet and in Expt 2 a high-roughage (HR) diet were given; the composition of the diets is shown in Table I. The lambs were given the experimental diets for I week before their confinement in metabolism stalls at a constant temperature of $22^{\circ}$ on a constant food intake, which was maintained during later infusion periods. Another week was allowed for the animals to adapt to the metabolism stalls, and during this period the jugular vein was catheterized. The diets provided $7 \cdot 49 \mathrm{MJ}(\mathrm{I} \cdot 79 \mathrm{Mcal})$ digestible energy. The daily $\mathrm{N}$ intake per lamb was $2 \mathrm{I} .0 \mathrm{~g}$ in Expt $\mathrm{r}$ and $\mathrm{r} 8.7 \mathrm{~g}$ in Expt 2.

Acetate, propionate, butyrate and glucose were administered intravenously on an isoenergetic basis to lambs given both diets, in two experiments of $4 \times 4$ Latin square design. The experiments were preceded by a saline infusion period (control) of $8 \mathrm{~d}$, when the lambs received $600 \mathrm{ml}$ isotonic saline solution into the jugular vein over $24 \mathrm{~h}$. The energy sources, infused for periods of $8 \mathrm{~d}$, provided $2.09 \mathrm{MJ}(0.5 \mathrm{Mcal}) / \mathrm{d}$ in $600 \mathrm{ml}$ fluid volume; this was equivalent to $22 \%$ of the total digestible energy. One additional lamb in each trial received saline infusion throughout the experiment.

Quantitative collections of faeces and urine were made on the 5 th, 6th, 7 th and 8 th days of each infusion period and the lambs were bled every and day throughout the experiment, $5 \mathrm{~h}$ after the last feed.

In the analysis of the individual plasma free amino acids, a Beckman Model No. I2I Automatic Amino Acid Analyser (Beckman Instruments Inc., Scientific Instruments Division, Fullerton, California 92634) was used, the separation of each sample taking $2 \mathrm{~h}$. The samples were prepared by the procedure of Hamilton (1963), which was modified by T. M. Badger (unpublished) as follows: $100 \mathrm{mg}$ sulphosalicylic acid were added to the centrifuge tubes; then $2 \mathrm{ml}$ plasma were pipetted into each tube and mixed for $40-60$ s on a micromixer.

Plasma amino acid $\mathrm{N}$ was determined by the following modification of the procedure of Hawk, Oser \& Summerson (1954): protein was precipitated with a mixture of 16 vol. water, I vol. of a solution containing I $00 \mathrm{~g}$ sodium tungstate/l and I vol. $0.67 \mathrm{~N}$-sulphuric acid; $3 \mathrm{ml}$ of filtrate were placed in $20 \mathrm{ml}$ test-tubes graduated at $10 \mathrm{ml}$. After the addition of $O .1 \mathrm{M}$-sodium hydroxide, the volume was made to $10 \mathrm{ml}$ with water before proceeding to the other steps; absorbance was read at $480 \mathrm{~nm}$ using a B \& L 'Spec 20' spectrophotometer (Bausch and Lomb, Scientific Instruments Division, Rochester, NY I4602).

PUN was determined by the modified procedure of Fawcett $\&$ Scott (r960), which is based on the Berthelot reaction (Preston, r968). The results were analysed by analysis of variance and Duncan's New Multiple Range test. 
Table 2. Expt I. Effect of intravenous infusions of $600 \mathrm{ml}$ isotonic saline solution/lamb per $d$ and of different energy sources, each providing 2.09 MY (0.5 Mcal)/lamb per d, on urinary and faecal nitrogen excretions and $N$ balance $(g / d)$

(Mean values for four lambs/treatment)

\begin{tabular}{lccc}
\multicolumn{1}{c}{ Substrate infused } & Urinary N & Faecal N & N balance \\
Saline* & $16 \cdot 84^{\mathrm{a}}$ & $2 \cdot 74^{\mathrm{a}}$ & $1 \cdot 44^{\mathrm{a}}$ \\
Glucose & $12 \cdot 69^{\mathrm{c}}$ & $2 \cdot 42^{\mathrm{a}}$ & $5 \cdot 89^{\mathrm{d}}$ \\
Acetate & $15^{\circ} \cdot 66^{\mathrm{b}}$ & $2 \cdot 34^{\mathrm{ab}}$ & $3 \cdot 00^{\mathrm{b}}$ \\
Propionate & $13 \cdot 23^{\mathrm{c}}$ & $2 \cdot 6^{\mathrm{a}}$ & $5 \cdot 3 \mathrm{1}^{\mathrm{d}}$ \\
Butyrate & $14 \cdot 73^{\mathrm{b}}$ & $1 \cdot 99^{\mathrm{b}}$ & $4 \cdot 28^{\mathrm{c}}$ \\
Standard error of the mean & $0 \cdot 37$ & $0 \cdot 16$ & $0 \cdot 35$
\end{tabular}

Significant differences $(P<0.05)$ are indicated by different superscripts by Duncan's New Multiple Range test.

* Mean values for five lambs.

\section{RESULTS}

There were no systematic effects associated with periods in the two experiments for the sheep on saline infusion throughout the experiments.

Expt $\mathbf{1}$. The effect on urinary $\mathrm{N}$, faecal $\mathrm{N}$ and $\mathrm{N}$ balance of administration of the different energy sources is presented in Table 2.

Glucose infusion was associated with the greatest decrease in urinary $\mathrm{N}$ excretion, followed by propionate, butyrate and acetate. The effects of glucose and propionate were similar, as were the effects of acetate and butyrate.

Faecal $N$ excretion was reduced by all treatments, but only the effect associated with butyrate infusion was significant $(P<0.05)$.

The $\mathrm{N}$ balance was increased significantly $(P<0.05)$ by all infusions. Acetate was least effective, whereas butyrate, propionate and glucose were increasingly effective in that order.

The effects of the different treatments on PUN concentrations are presented in Table 3. PUN concentration was significantly reduced by all infusions $(P<0 . \mathrm{OI})$ except glucose infusion, which produced a non-significant increase. Acetate and butyrate depressed PUN concentration to the same degree; an even lower depression was observed with propionate infusion.

As shown in Table 3 , the plasma free amino acid $N$ concentration was reduced (not significant) by all infusions below the concentration associated with the control infusion. The effect was greatest with butyrate, followed by propionate, acetate and glucose.

The effects of the different energy sources on the individual plasma amino acids are presented in Table 4 . Lysine and arginine concentrations were lowered by intravenous administration of additional energy (not significant).

The concentration of alanine was significantly lower during acetate and butyrate infusions than during glucose infusions. Glucose and propionate infusions resulted in a non-significant increase in the concentration of alanine compared with the control infusion. The methionine concentration was significantly depressed by all infusions, but there were no significant differences due to energy source. 
Table 3. Expt $\mathrm{I}$. Effect of intravenous infusions of $600 \mathrm{ml}$ isotonic saline solution/lamb per $d$ and of $600 \mathrm{ml}$ of different energy sources, each providing 2.09 MY (0.5 Mcal)/lamb per $d$, on mean plasma urea nitrogen and plasma free amino acid $N$ concentrations $(\mathrm{mg} / \mathrm{l})$

\begin{tabular}{lcc}
\multicolumn{2}{c}{ (Mean values for four lambs/treatment) } & $\begin{array}{c}\text { Plasma free } \\
\text { Substrate infused }\end{array}$ \\
Panino acid N
\end{tabular}

Significant differences $(P<0.05)$ are indicated by different superscripts by Duncan's New Multiple Range test.

* Mean values for five lambs.

Table 4. Expt $\mathrm{x}$. Plasma free amino acid concentration ( $\mathrm{mg} / \mathrm{l})$ at the 6 th day of infusion of $600 \mathrm{ml}$ isotonic saline solutiom/lamb per $d$ and of $600 \mathrm{ml}$ of different energy sources (each proziding 2.09 $\mathrm{MY}(0.5 \mathrm{Mcal}) /$ lamb per $d)$

\begin{tabular}{|c|c|c|c|c|}
\hline \multicolumn{5}{|c|}{ (Mean values with their standard errors for four lambs/treatment) } \\
\hline $\begin{array}{c}\text { Substrate } \\
\text { infused }\end{array}$ & Lysine & Arginine & Alanine & Valine \\
\hline Saline & $17 \cdot 6^{\mathrm{a}}$ & $2 \mathrm{I} \cdot 8^{\mathrm{a}}$ & $35^{\cdot 2^{\mathrm{ab}}}$ & $15^{\cdot 2^{a}}$ \\
\hline Glucose & $I I \cdot 4^{a}$ & $17 \cdot 2^{a}$ & $4 \mathrm{I} \cdot 6^{\mathrm{a}}$ & $8 \cdot 7^{b}$ \\
\hline Acetate & $I 4^{\cdot} \mathrm{O}^{\mathrm{a}}$ & $14 \cdot 9^{a}$ & $26 \cdot 4^{b}$ & $14.5^{\mathrm{a}}$ \\
\hline Propionate & $12 \cdot 7^{a}$ & $15 \cdot 2^{a}$ & $37 \cdot 0^{\mathrm{ab}}$ & $11 \cdot 4^{a b}$ \\
\hline Butyrate & $13 \cdot x^{a}$ & $16 \cdot 9^{a}$ & $24^{\cdot} 6^{\mathrm{b}}$ & $13 \cdot 6^{a}$ \\
\hline $\begin{array}{l}\text { Standard error } \\
\text { of the mean }\end{array}$ & $I \cdot 6$ & 2.0 & 47 & $I \cdot 3$ \\
\hline Methionine & Isoleucine & Leucine & Tyrosine & Phenylalanine \\
\hline $3 \cdot 5^{\mathrm{a}}$ & $7 \cdot 9^{\mathrm{a}}$ & $12 \cdot 7^{\mathrm{a}}$ & $4^{8^{a}}$ & $4^{-2^{a}}$ \\
\hline $1 \cdot 3^{b}$ & $3 \cdot 5^{b}$ & $6 \cdot 0^{b}$ & $6 \cdot 5^{2}$ & $2 \cdot 8^{a}$ \\
\hline$I \cdot 3^{b}$ & $7 \cdot 1^{2}$ & $I I \cdot 2^{a}$ & $6 \cdot 1^{a}$ & $5^{-0^{2}}$ \\
\hline $0.9^{b}$ & $5 \cdot 8^{\mathrm{ab}}$ & $8 \cdot 6^{\mathrm{ab}}$ & $5 \cdot 7^{\mathrm{a}}$ & $3^{\cdot 6^{\mathrm{a}}}$ \\
\hline $2 \cdot 0^{b}$ & $7 \cdot 0^{a}$ & $10 \cdot 7^{\mathrm{a}}$ & $5 \cdot 2^{a}$ & $4^{\circ} 9^{\mathrm{a}}$ \\
\hline 0.3 & 0.6 & $I \cdot I$ & $x \cdot 1$ & 0.8 \\
\hline
\end{tabular}

Significant differences $(P<0.05)$ are indicated by different superscripts by Duncan's New Multiple Range test.

The concentrations of valine, isoleucine and leucine followed the same trend in their responses to the different treatments. Acetate and butyrate infusions did not significantly reduce the plasma concentrations of these three essential amino acids; infusion of glucose lowered their concentrations $(P<0.01)$ and the response of propionate infusion was intermediate between those of acetate and glucose and was not significantly different from any of the other treatments.

The plasma concentrations of phenylalanine and tyrosine were not significantly affected by any of the infusions.

Expt 2. The mean values for urinary $\mathrm{N}$, faecal $\mathrm{N}$ and $\mathrm{N}$ balance are shown in Table 5 . 
Table 5. Expt 2. Effect of intravenous infusions of $600 \mathrm{ml}$ isotonic saline solution/lamb per $d$ and of $600 \mathrm{ml}$ of different energy sources each providing 2.09 MY ( $0.5 \mathrm{Mcal}) /$ lamb per $d$, on mean daily urinary and faecal nitrogen concentrations and $N$ balance $(g / d)$

(Mean values for four lambs/treatment)

\begin{tabular}{lccc}
\multicolumn{1}{c}{ Substrate infused } & Urinary N & Faecal N & N balance \\
Saline* & $12 \cdot 84^{\mathrm{a}}$ & $5 \cdot 72^{\mathrm{a}}$ & $0.14^{\mathrm{a}}$ \\
Glucose & $9 \cdot 86^{\mathrm{b}}$ & $5 \cdot 27^{\mathrm{b}}$ & $3.57^{\mathrm{b}}$ \\
Acetate & $10 \cdot 8^{\mathrm{c}}$ & $5 \cdot 25^{\mathrm{b}}$ & $2 \cdot 67^{\mathrm{c}}$ \\
Propionate & $9 \cdot 03^{\mathrm{d}}$ & $5 \cdot 22^{\mathrm{b}}$ & $4.45^{\mathrm{d}}$ \\
Butyrate & $10 \cdot 33^{\mathrm{bc}}$ & $5.07^{\mathrm{b}}$ & $3.30^{\mathrm{bc}}$ \\
Standard error of the mean & $0 \cdot 28$ & 0.16 & 0.28
\end{tabular}

Significant differences $(P<0.05)$ are indicated by different superscripts by Duncan's New Multiple Range test.

* Mean values for five lambs.

Table 6. Expt 2. Effect of intravenous infusions of $600 \mathrm{ml}$ isotonic saline solution/lamb per $d$ and of $600 \mathrm{ml}$ of different energy sources each providing 2.09 MJ ( $0.5 \mathrm{Mcal})$ /lamb per $d$ on mean plasma urea nitrogen and plasma free amino acid $N$ concentrations $(m g / l)$

(Mean values with their standard errors for four lambs/treatment. Four blood samples were taken from each of the lambs and in each treatment group)

Substrate infused

Saline*

Glucose

Acetate

Propionate

Butyrate

Standard error of the mean
Plasma urea $\mathrm{N}$

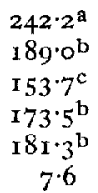

Plasma free amino acid $\mathrm{N}$

$5.3^{\circ}$

$4 \mathrm{I}^{\mathrm{b}}$

$3^{8 \cdot 2^{\mathrm{bc}}}$

$37 \cdot I^{\mathrm{c}}$

$37 \cdot 1^{\mathrm{c}}$

1.8

Significant differences $(P<0.05)$ are indicated by different superscripts by Duncan's New Multiple Range test.

* Mean values for five lambs.

Urinary $\mathrm{N}$ excretion was reduced by all infusions. The greatest effect was produced by propionate infusion $(P<0.05)$, followed by glucose, butyrate and acetate.

Faecal $\mathrm{N}$ excretion was significantly decreased by all infusions $(P<0.05)$. The greatest reduction resulted from the infusion of butyrate.

$\mathrm{N}$ balance increased significantly with all infusions. The largest increase was observed after propionate infusion, followed by glucose, butyrate and acetate.

The effects of intravenous infusion of saline, glucose, acetate, propionate and butyrate on concentrations of PUN and plasma free amino acid nitrogen are presented in Table 6. All the infusions significantly reduced PUN concentration $(P<0.01)$, the greatest reduction being produced by acetate, followed by propionate, butyrate and glucose.

All the infusions significantly decreased $(P<0.01)$ plasma free amino acid $\mathrm{N}$ concentration. Propionate and butyrate were most effective followed by acetate and glucose. The effects of acetate, propionate and butyrate were not significantly different $(P>0.05)$. The effect of glucose was not significantly different from that of acetate. 
Table 7. Expt 2. Mean plasma free amino acid concentration $(\mathrm{mg} / \mathrm{l})$ at the 6 th day of infusion of $600 \mathrm{ml}$ isotonic saline solution/lamb per $d$ and of $600 \mathrm{ml}$ of different energy sources (2.09 MY (0.5 Mcal) /lamb per d)

\begin{tabular}{|c|c|c|c|c|}
\hline \multirow[b]{2}{*}{$\begin{array}{c}\text { Substrate } \\
\text { infused }\end{array}$} & \multicolumn{3}{|c|}{ (Mean values for four lambs/treatment) } & \multirow[b]{2}{*}{ Valine } \\
\hline & Lysine & Arginine & Alanine & \\
\hline Saline & $29 \cdot I^{\mathrm{a}}$ & $27^{2} 2^{a}$ & $40.8^{\mathrm{a}}$ & $20 \cdot 2^{\mathrm{a}}$ \\
\hline Glucose & $18 \cdot 0^{b}$ & $14.5^{\mathrm{b}}$ & $42 \cdot 6^{a}$ & $I_{4} \cdot 6^{a}$ \\
\hline Acetate & I $9 \cdot 3^{b}$ & $\mathrm{I}_{4} \cdot \mathrm{I}^{\mathrm{b}}$ & $24 \cdot 5^{b}$ & $19 \cdot 9^{a}$ \\
\hline Propionate & $17 \cdot 3^{\mathrm{b}}$ & $15 \cdot 3^{\mathrm{b}}$ & $45 \cdot 5^{\mathrm{a}}$ & $15 \cdot 4^{a}$ \\
\hline Butyrate & $18 \cdot 5^{\mathrm{b}}$ & $16 \cdot 2^{b}$ & $37^{\circ} 5^{\mathrm{ab}}$ & $20 \cdot 2^{a}$ \\
\hline $\begin{array}{l}\text { Standard error } \\
\text { of the mean }\end{array}$ & $2 \cdot 4$ & $1 \cdot 7$ & $4 \cdot 8$ & $2 \cdot 3$ \\
\hline Methionine & Isoleucine & Leucine & Tyrosine & Phenylalanine \\
\hline $\begin{array}{l}3 \cdot 5^{\mathrm{a}} \\
\mathrm{I} \cdot 6^{\mathrm{b}}\end{array}$ & $\begin{aligned} \operatorname{Ir} \cdot 7^{\mathrm{a}} \\
5 \cdot 0^{\mathrm{b}}\end{aligned}$ & $\begin{array}{r}17 \cdot 4^{\mathrm{a}} \\
8 \cdot 6^{\mathrm{b}}\end{array}$ & $\begin{array}{l}7 \cdot 5^{\mathrm{a}} \\
6 \cdot 8^{\mathrm{a}}\end{array}$ & $\begin{array}{l}5 \cdot 3^{\mathrm{a}} \\
4 \cdot 1^{\mathrm{a}}\end{array}$ \\
\hline $\mathrm{r} \cdot 2^{\mathrm{b}}$ & $8 \cdot 9^{\mathrm{ab}}$ & $I 2 \cdot I^{c}$ & $5 \cdot 2^{a}$ & $5 \cdot 3^{a}$ \\
\hline $2 \cdot I^{b}$ & $7 \cdot 7^{\mathrm{b}}$ & $10.6^{\mathrm{bc}}$ & $5 \cdot 5^{\mathrm{a}}$ & $4 \cdot 7^{a}$ \\
\hline$r \cdot 9^{b}$ & $\operatorname{II} \cdot 2^{\mathrm{a}}$ & $\mathrm{II} \cdot 4^{\mathrm{bc}}$ & $5 \cdot 8^{a}$ & $4 \cdot 5^{\mathrm{a}}$ \\
\hline 0.3 & $x \cdot 0$ & $\mathrm{I} \cdot 4$ & 0.9 & 0.5 \\
\hline
\end{tabular}

Significant differences $(P<0.05)$ are indicated by different superscripts by Duncan's New Multiple Range test.

Significant differences between treatments were observed for the following amino acids (see Table 7 ): lysine, arginine, alanine, methionine, isoleucine and leucine. Plasma concentrations of lysine, arginine and methionine were not specific in their response to the different energy sources. All infusions significantly reduced plasma values below those associated with the control period $(P<0.05)$.

Significant differences due to specific energy sources were obtained for alanine, isoleucine and leucine. The response of alanine was opposite to that of the other amino acids studied, since only acetate infusion significantly lowered the plasma free alanine concentration.

Valine was most reduced by glucose and propionate infusions (not significant) compared with the values associated with control, acetate and butyrate infusions. The concentration of isoleucine was significantly reduced by glucose and propionate infusions $(P<0.0 I)$ and by butyrate infusions compared with saline infusion; the response to acetate infusion was not significantly different from that to any of the other treatments.

Leucine concentration showed the greatest reduction during glucose infusion, followed by propionate, butyrate and acetate. The effects of glucose and propionate infusions and of acetate, propionate and butyrate infusions were not significantly different from each other. Tyrosine and phenylalanine concentrations were not significantly affected by the different infusions.

\section{DISCUSSION}

The results reported herein were obtained by direct infusion into the systemic blood, thus bypassing the rumen epithelium, where major conversion of butyrate into ketone 
bodies may occur, and the portal system which would generally result in conversion of propionate into glucose and the formation of additional ketone bodies. Our results obtained with propionate and butyrate, therefore, may differ from results obtained by others with intraruminal infusion of the energy source.

The specific effects of the intravenously administered energy sources upon excretion of urinary $\mathrm{N}$ and faecal $\mathrm{N}$ and on $\mathrm{N}$ balance found in earlier experiments are discussed elsewhere (Eskeland et al. 1973). The $\mathrm{N}$ balance results of the two experiments described here will be used to relate these values to plasma concentrations of free amino acids and PUN. The average $\mathrm{N}$ retentions were $5^{\cdot 89}, 5 \cdot 3 \mathrm{I}, 4 \cdot 28$ and $3^{\circ} \cdot 00 \mathrm{~g} / \mathrm{d}$ for glucose, propionate, butyrate and acetate respectively in Expt $\mathrm{I}$, and $3 \cdot 57,4 \cdot 45,3 \cdot 30$ and $2 \cdot 67 \mathrm{~g} / \mathrm{d}$ respectively in Expt 2. Thus glucose and propionate were more effective as energy sources for protein deposition than butyrate, and acetate was the least effective.

The changes in the plasma concentrations of the free amino acids following intravenous infusion of acetate, propionate, butyrate and glucose showed the same trend in both experiments. The lambs receiving the HR diet with a lower total $\mathrm{N}$ intake than lambs given the $\mathrm{HC}$ diet had higher levels of all plasma free amino acids investigated.

Blood urea is commonly considered to be a metabolic end-product of protein catabolism, and ingestion of excess $\mathrm{N}$ by ruminants results in a proportional increase in ruminal ammonia and subsequently in PUN concentration. Urea is recycled to the rumen from the plasma either across the rumen wall (Houpt, 1959; Houpt \& Houpt, I968), or in saliva (McDonald, I958; Somers, r961), and is utilized by the microorganisms for protein synthesis in the rumen with concomitant energy consumption (Packett \& Groves, 1965 ).

The blood urea $\mathrm{N}$ (BUN) concentration in lambs was altered by varying the source of dietary carbohydrate and protein (Preston, Breuer \& Pfander, I96I) and BUN concentration in cattle was affected by dietary levels of protein and energy (Preston, Breuer \& Thompson, I961). When steers were fed on high- or low-protein diets at three levels of energy intake, the effect of increasing energy content but not the protein content was a reduction in the BUN concentration.

In the study by Preston \& Pfander (1963) BUN concentration was directly proportional to the dietary protein content and inversely proportional to the dietary energy content. They concluded that it is a sensitive indicator of protein adequacy, as it is affected by the energy intake. When BUN concentration was plotted as a function of the energy: $\mathrm{N}$ ratio of the diet a high correlation resulted $(r=-0.96)$.

In our studies the correlation coefficients obtained between PUN concentration and the $\mathrm{N}$ retention were 0.16 for Expt 1 and -0.65 for Expt 2.

In Expt $\mathrm{I}$, acetate was only $5 \mathrm{I} \%$ as effective as glucose, $57 \%$ as effective as propionate and $70 \%$ as effective as butyrate in promoting $\mathrm{N}$ retention. The respective PUN values were $283.3,201 \cdot 0,221 \cdot 2$ and $205 \cdot 7 \mathrm{mg} / \mathrm{l}$ for the glucose, acetate, propionate and butyrate treatments, respectively, and were not inversely correlated to $\mathrm{N}$ retention $(r=0 \cdot 16)$.

The mechanism whereby the PUN values were maintained at such high concentrations during glucose infusion, and even higher than the control value, is not understood. Better agreement between reduced PUN values and increased $\mathrm{N}$ retention 
$(r=-0.65)$ was obtained in Expt 2; however, with acetate infusion the increase in $\mathrm{N}$ retention was the smallest, but PUN concentrations were significantly lowest during that treatment.

In these experiments $\mathrm{N}$ intake exceeded requirements, and dietary energy was limited in order to detect specific responses in growth brought about by intravenous infusion of the different energy sources. Under these experimental conditions, PUN concentration was not appropriate to assess the protein status of the animal.

The relative increase in plasma amino acids in the lambs given the HR diet may have been the result of less energy being available for protein synthesis or, alternatively, the result of more dietary protein reaching the small intestine (duodenum). This response corresponds to a reduced $\mathrm{N}$ balance for lambs on the HR diet compared with those on the $\mathrm{HC}$ diet. The plasma concentrations of valine, isoleucine, leucine and phenylalanine in both experiments were decreased to $57,7 \mathrm{I}, 89$, and $90 \%$ of control values by glucose, propionate, butyrate and acetate infusions, respectively. These results are similar to those of Potter et al. (1968) who, upon rapid infusion of glucose, propionate, butyrate or acetate, reported average plasma essential amino acid indices (defined as [the plasma free amino acid (PFAA) concentration after energy infusion divided by the PFAA concentration before energy infusion] $\times 100$ ) of $59,66,85$ and 90 , respectively. In our study the depression in the listed essential amino acids was inversely correlated with the $\mathrm{N}$ balance values, suggesting that plasma free amino acids were removed for protein synthesis.

Essential amino acid concentrations were not significantly depressed below control values when acetate was infused, which suggests that amino acids were not removed in quantity from the plasma pool. The results may be explained in part by the results of Mayfield, Bensadoun \& Johnson (1966), who showed that the relative rate of ${ }^{14} \mathrm{CO}_{2}$ production from $\left[{ }^{1-}{ }^{14} \mathrm{C}\right]$ acetate by ruminant tissues decreased in the following order: adipose, kidney, muscle, heart, lung, brain, liver. It is possible that glucose and acetate were metabolized by different tissues, and that cellular uptake or protein synthesis per unit of energy in these tissues was not equal.

The non-specific behaviour of lysine, methionine and arginine in lambs receiving energy infusion was not accounted for.

Our results suggest two mechanisms through which glucose and, to a lesser extent, propionate are more effective energy sources in protein synthesis than acetate or butyrate: ( 1 ) depression of plasma essential amino acids following increased cellular uptake of amino acids; (2) formation of non-essential amino acids to allow growth. The lowered concentrations of plasma amino acids after ingestion of glucose by human subjects have been shown to be mediated by insulin (Crofford, Felts \& Lacy, I964). In ruminants insulin is of much less importance as a regulator of blood glucose concentration than it is in simple-stomached animals. The first mechanism, however, is somewhat contra-indicated by our finding that the concentration of some nonessential amino acids increased, leaving the possibility that glucose is effective because it permits greater synthesis of non-essential amino acids to allow growth.

The concentration of alanine was increased after both glucose and propionate infusions, compared with acetate and butyrate infusions. In a study by Black, Kleiber 
\& Baxter (I955), a cow was intravenously injected with [U-14 C]glucose and the source of the amino acids of casein was investigated. Alanine and serine were rapidly synthesized from glucose and the results indicated that $25 \%$ of alanine was derived from plasma glucose. Propionate was not important as a precursor of alanine (Black $\&$ Kleiber, 1958). Acetate was the most efficient carbon source for glutamic and aspartic acids and a less efficient carbon donor for alanine (Black, Kleiber, Smith \& Stewart, I957), which agrees with our results since reduced alanine concentration was observed during acetate infusion. Butyrate appeared to be more important as a precursor for some of the other non-essential amino acids than for alanine (Black, Kleiber \& Brown, I96I).

The decreased ratios of essential to non-essential amino acid observed after ingestion of glucose in the studies of Swendseid, Griffith \& Tuttle (1963) and Swendseid, Villalobos \& Freidrich ( 1963$)$ were the result of a decrease in essential amino acids and often resulted in increased concentrations of non-essential amino acids. This was thought to be due to continued synthesis of non-essential amino acids despite restricted protein synthesis. The same trend was observed in the study by Potter et al. (1968) where concentrations of non-essential amino acids were increased.

There was no relationship between plasma free amino acid $\mathrm{N}$ concentrations and increased $\mathrm{N}$ retention in Expts $\mathrm{I}$ and 2. Glucose infusion was least effective in lowering plasma free amino acid $\mathrm{N}$ concentration, but this effect was not significant. The limited effect of glucose (in Expts $x$ and 2) may be attributed to synthesis of non-essential amino acids, as observed for alanine, accompanied by a reduction in all the essential amino acids evaluated.

In our studies, cellular uptake of amino acids or protein synthesis is suggested, since increased $\mathrm{N}$ retention with the individual treatments was closely related to decreased concentrations of plasma free essential amino acids, though other interpretations of decreases in plasma free amino acids have been offered (Holden, I962; Munro, 1964).

Sincere thanks are extended to Dr. Myron E. Tumbleson of Veterinary Physiology and Pharmacology for use of the amino acid analyser and to Dr Tom Badger for help with the analyses.

\section{REFERENCES}

Black, A. L. \& Kleiber, M. (1958). F. biol. Chem. 232, 203.

Black, A. L., Kleiber, M. \& Baxter, C. F. (1955). Biochim. biophys. Acta 17, 346.

Black, A. L., Kleiber, M. \& Brown, A. M. (196 I). F. biol. Chem. 236, 2399.

Black, A. L., Kleiber, M., Smith, A. H. \& Stewart, D. N. (1957). Biochim. biophys. Acta 23, 54.

Crofford, O. B., Felts, P. W. \& Lacy, W. W. (r 964). Proc. Soc. exp. Biol. Med. xx7, I1.

Eskeland, B., Pfander, W. H., Badger, T. M. \& Preston, R. L. (I971). J. Anim. Sci. 33, 282.

Eskeland, B., Pfander, W. H. \& Preston, R. L. (1973). Br. F. Nutr. 29, 347.

Eskeland, B., Preston, R. L. \& Pfander, W. H. (197 I). Fedn Proc. Fedn Am. Socs exp. Biol. 30, 403.

Fawcett, J. K. \& Scott, J. E. (1960). F. clin. Path. 13, I56.

Hamilton, P. B. (1963). Ann. N.Y. Acad. Sci. ro2, 55.

Hawk, P. B., Oser, B. L. \& Summerson, W. H. (1954). Practical Physiological Chemistry i 3 th ed., p. 565. New York: Blakiston Co.

Holden, J. T. (1962). Amino Acid Pools. New York: Elsevier.

Houpt, T. R. (1959). Am. F. Physiol. r97, i I 5 -

Houpt, T. R. \& Houpt, K. A. (1968). Am. F. Physiol. 214, 1296.

McDonald, I. W. (r958). Proc. Aust. Soc. Anim. Prod. 2, 46. 
Mayfield, E. D., Bensadoun, A. \& Johnson, B. C. (1966). F. Nutr. 89, I89.

Munro, H. N. (1964). In Mammalian Protein Metabolism. Vol. 1, pp. 273, 283 [H. N. Munro and J. B. Allison, editors]. New York: Academic Press.

Ørskov, E. R. \& Allen, D. M. (1966). Br. F. Nutr. 20, 5 I 9.

Packett, L. V. \& Groves, T. D. D. (1965). F. Anim. Sci. 24, 34 I.

Potter, E. L., Purser, D. B. \& Cline, J. H. (1968). F. Nutr. 95, 655 .

Preston, R. L. (1968). Proc. Soc. exp. Biol. Med. 129, 250.

Preston, R. L., Breuer, L. H. \& Pfander, W. H. (r96r). F. Anim. Sci. 20, 947.

Preston, R. L., Breuer, L. H. \& Thompson, G. B. (r96r), f. Anim. Sci. 20, 977.

Preston, R. L. \& Pfander, W. H. (1963). F. Anim. Sci. 22, 844.

Rook, J. A. F., Balch, C. C., Campling, R. C. \& Fisher, L. J. (1963). Br. F. Nutr. 17, 394

Somers, M. (1961). Aust. F. exp. Biol. med. Sci. 39, 145.

Swendseid, M. E., Griffith, W. H. \& Tuttle, S. G. (1963). Metabolism 12, 96.

Swendseid, M. E., Villalobos, J. \& Freidrich, B. (1963). F. Nutr. 80, 99.

Van Soest, P. J. (1967). Y. Anim. Sci. 26, Ir9. 